\title{
A Review of Management Earning and Real Transaction Manipulations Pre and Post IFRS Adoption in Nigeria
}

\author{
Obi Chineze Eunice \\ Department of Accountancy, Faculty of Management Science University of Nigeria, Nsukka, Nigeria
}

\section{Email address:}

obi_chineze@yahoo.com

\section{To cite this article:}

Obi Chineze Eunice. A Review of Management Earning and Real Transaction Manipulations Pre and Post IFRS Adoption in Nigeria. Journal of Investment and Management. Vol. 10, No. 1, 2021, pp. 8-12. doi: 10.11648/j.jim.20211001.12

Received: September 23, 2020; Accepted: November 17, 2020; Published: April 16, 2021

\begin{abstract}
The paper examined the accounting quality in the financial statement, concerning earnings management practices by managers. The financial statements provide critical information that is useful to various groups, investors, standard setters, shareholders and government. The practices of various methods of earnings management are classified into accounting-based and market- based earnings management. The study classified the earnings management techniques in various ways that affect the quality of financial statements in the pre and post-IFRS adoption. The introduction of IFRS and its accompanying standards in the area of earnings management might imply real improvements in the financial statements about the quality. The earnings management techniques include the following: earnings management towards a target, earnings smoothing, discretionary accruals, accruals quality, and timely loss recognition as against other proxies of accounting quality. These are opportunities managers have to get quality Financial Statements that accomplish their intentions. The essence is that they use them to achieve their objectives either getting the desired level of profit or not recording losses for the business. The review results are that in the pre-IFRS the earnings management in use was the accrual-based earnings technique in which managers adjust assumptions and estimates the accounting system. In the post-IFRS, managers revert to real transactions based earnings management which involves the timing and structuring actual business activities to achieve a desired financial reporting result (for example, the timing of the sale of equipment that will result in a gain in a quarter in which extra earnings are needed, delaying major repairs, advertising, research, and development expenses write-off, and foregoing capital projects that positive net present value).
\end{abstract}

Keywords: Revenue, Earnings, Management, Government, Nigeria

\section{Introduction}

The questions often asked when firms or companies fail/bankruptcy is how reliable is the financial statements issued by those firms/companies. These questions had been in the background, but the recent wave of companies' failures/corporate accounting scandals had brought the issues into the limelight. (Enroll scandals, the passage of the [26]. There had been earlier written ups or researches about some of the reasons for the failures. had cited some of the views expressed by the financial press as to the importance of meeting Wall Street's expectations, often asked the question "Did you make your earning last quarter? [5]. They went ahead to state that meeting or beating analysts forecasts of earnings would be noted to have been entrenched in coorperate culture [33]. Many other researchers had stated that many active players had joined by altering reported earnings or managing analysts' expectations [5]. He had stated that prior research identified that firm' earnings management was for purposes of beating/meeting important earnings benchmark [7]. They stated that earnings management was causing an erosion in the quality of earnings and the quality of financial reporting, while found that restructuring charges an average 80 percent of net income before the charge [29] [13]. Schuvetz observed that firms had increased tendencies of reversing their earlier restructuring charges [35]. Some other researchers report the financial press stating the three reasons why managers manage earnings to include; to state profit that is at least above zero, sustain recent previous year performance and to meet analysts' expectations.

Another aspect of the literature had recognized the "lemons problems, a situation where the capital providers 
cannot assess the firm's profitability and over-price firms with low profitability, therefore, leading to market failure [2]. These events showed that earnings management had been in practice long ago but in the areas of meeting/beating analysts' earnings expectations and the accrual earnings management. But recently after the accounting scandals which resulted in the passage of the researchers had recorded a new wave of earnings management [26]. Most researchers had found that earnings management had shifted from the previous ones to real activities manipulations [32, 7, 4, 22]. This paper is aimed to review earnings management in the pre and postSarbanes-Oxley period and also post IFRS adoption by most companies in the financial accounting statements.

\section{Review of Literatures}

The investigation of earnings management in the Islamic banks to know whether earnings were managed or not, either to decrease losses and avoid decreases [19]. They used the earning distribution approach (EDA), their findings confirmed the assumption with the statistical test that earnings were managed to avoid losses. Also that the Islamic banks that were above the earning threshold were risk averters and those of them below the earning threshold were found to be risk seekers. Finally, the accepted hypothesis showed that prospect theory explained the Islamic bank's motivation in managing earning to exceed the thresholds.

The Research that value relevance of accounting information of quoted companies in Nigeria [1]. Using the ordinary least square (OLS) regression method, it was observed that accounting information of Nigerian firms is value relevance based. The value relevance did not follow a particular trend but rather in a period of political crisis, (1992-1998) the value relevance was weak and also during the global economic crisis between 2005 and 2009. All other periods of the study, the value relevance was high.

The studies on the effect of Real Activities Manipulation on Accrual Earnings Management stated that the three ways of managing earnings were accrual management, real activities management, and core expenses shifting [19]. Among these three methods of managing earnings, the famous ones were accruals earnings management and real activities manipulation findings were that the real activities manipulation positively influenced accrual earnings management and that the higher the real activities manipulation effects, the higher would be the accruals earnings management at the end of the period [25].

They investigated whether the IFRS standards versus US GAAP standards of accounting system results in amounts were comparable [30]. They found that IFRS firms had a greater accounting system and value relevance than the US GAAP and that comparability was greater for firms than adopted IFRS mandatorily, both in common low and high enforcement countries. The areas of comparability were earnings smoothing, accrual quality and timeless but there was still a significant difference between IFRS and US GAAP but IFRS enhanced financial reporting comparability with US firms $[17,16]$.

It was stated that previous research had identified that firms with high accruals were more likely to experience future earnings problems but investors' expectations as reflected in stock prices had not anticipated these problems [10]. Therefore, in their research, the study published opinions of two types of professional investor intermediaries to see if whether investor's information about future earnings problems was because firms identified with high accruals. The findings included that auditors and analysts would not alert investors of the future earnings problems associated with high accruals.

He examined the difficulties of previous studies on the effect of IFRS on accounting quality because of controlling for confounding factors on accounting quality [34]. They provided for these confounding factors by using five indicators as proxies for accounting qualities: These variables were, managing earnings towards a target, a lower magnitude of absolute discretionary accruals, earnings smoothing, less timely recognition of large losses and accrual quality. Then, using a unique research technique, they addressed the issue by comparing the accounting quality of 15 publicly listed companies of 15 member states of the European Union; they showed that the improved accounting quality was attributable to IFRS rather than changing in managerial incentives. Institutional features of capital markets, general business environment [24].

The study was on how the value relevance research assessed accounting amounts which showed information used by investors and helped the interest of standard setters. They further stated that the main user of financial statements should be the equity investors, but other uses as for contracting would not diminish the importance of value relevance research [25]. Also, the value relevance studies could be used to address econometric issues that could otherwise limit inferences and would accommodate, and be used to study the implications of accounting conservatism [31].

Questioned and interviewed to examine the factors to drive reported earnings and disclosure. The findings were that managers would rather take economic actions that could have negative long-term consequences than making within GAAP accounting choices to manage earnings [28]. The managers tried to maintain predictability in earnings and financial disclosures to reduce information risk and boost the stock price. Also, I tried to avoid setting disclosure precedent that they could not be maintained. Other research on how managers tried to avoid earnings decreases and losses. The findings were that Danish firms managed earnings so that there would be neither earnings decreases nor losses [21].

The investigation on the relationship between the cost of equity capital and seven attributes of earnings. This attribute of earnings was accrual quality, persistence, predictability, smoothness, value relevance, timeless and conservatism, then classified them into one, accounting base because they could be measured using accounting information and secondly those that they were characterized as market-based, as they 
are proxies between market-based and accounting information using theoretical models which predicted positive association between information quality and cost of equity [24]. They tested and found out that firms that had the least favorable values, individually of the attributes had a larger cost of equity than firms with higher favorable values. Also, firms that had the largest cost of equity were ones that had an accounting-based attribute, in particular, accrual quality [16].

The Studies on the way capital market pressures and institutional structures made firms' incentives to report earnings that showed a true picture of their economic performance [13]. He examined earnings management incentives to exceed the threshold [22]. They stated the reasons why analysts, investors, and boards of directors were so keen on this, were that earnings provide critical information for investment decisions and board of directors used it to monitor manager's performance.

They examined timing off Asset Sales and Earnings Manipulation. They used two hypotheses of explanations for earning manipulations, earnings-smoothing and debt-equity hypotheses [6]. They stated that a manager could often choose the period during which asset would be sold, and managers would be expected to report. While practitioners and regulators realized the problems of earnings management and wished that it could be remedied [18].

Other researchers stated that restructuring charges were used to manage earnings [29]. Restructuring charges here meant were for the current period recognition of the estimated amount of current and future costs associated with the restructuring activities, like, work-force reductions and the redesign of unprofitable operations. These restructuring charges could be very high as stated in their studies that these average 80 percent of net income before the charge [11].

They examined large sample evidence of how managers avoiding reporting annual losses or missing analyst forecasts by manipulating sales, reducing discretionary expenditures and overproducing inventory to decrease the cost of goods sold, all these were towards making sure that earnings were biased upward, using non-optional operation decisions [22].

Others in their research found that firms that used earning benchmarks by engaging in real activities manipulation, had performed well during the subsequent three years than firms that did not engage in real activities manipulation [23].

They studied the case of overvaluation as an incentive for earnings management. The findings included that during the period of overvaluation managers used accrual earnings management in the earlier years and real activities manipulations in later years and non-GAAP earnings management as of last resort [4].

Other researchers in their study about management's incentives to avoid negative earnings surprises, hypothesized to associate with greater incentives tried to avoid negative surprises [14]. That is, firms that manager tried to manage to earn upward or guided analysts' forecasts downwards, so that expectation could be met at the announcement [15]. The findings stated that firms with higher transient institutional ownership, greater reliance on implicit claims with their stakeholders, and higher value relevance of earnings were more likely to meet or exceed expectations at the earnings announcement [15].

It was stated that academics were unwilling to believe that earnings management was practiced by most firms or that earnings management which was practiced should be a concern to investors [13].

They investigated if managers used real activities manipulation and accrual-based earnings management as substitutes in managing earnings [3]. Using an empirical model that incorporated the costs associated with the two earnings methods and managers' outcome decision, they found 11that managers used real activities manipulation and accrual-based earnings management as substitutes.

\section{Discussion}

The argument had been how far financial statements have produced a true and fair view. In this regard, there had been many developments as to how much convergence in the reports of the financial statements that will make the financial statements a true reporting of facts. They had stated that the adoption of IFRS had produced a pro side of the event by the success of developing standards that have a comprehensive set of high quality [4]. The articles reviewed had shown the trend of the true picture of events for pre and post IFRS and Sarbene Act proclamations. Some researchers had stated that adopting IFRS would result in a fundamental change in the business environment since companies in different countries used a various variety of the Generally Accepted Accounting Principles (GAAP) as prescribed in their countries where they operate. But many studies agree to the fact that financial statements prepared under the IFRS and the Sarbanes Oxley Act had fewer earnings management using accruals, it now managed through real transaction manipulations. Some authors had stated that when firms adopted IFRS had practiced fewer earnings management more timely recognition of losses it implied higher value relevance of accounting of earnings $[18,11,12,21]$.

\section{Conclusion}

The study reviewed the literature on earnings management and real transactions manipulations pre and post IFRS. In the review, there is evidence of earnings management and real transaction manipulation in both the era of pre and post-IFRS. But the enactment of the Sarbanes Oxley Act (Sox, 2002) helped to reshape the practices on the earnings management. It shows that from the passage of the Act, earnings management practice shifted from the accrual-based earnings management to real transactions/activities manipulations. There are about three ways found in the review, the accrualbased earnings management, real transactions/activities manipulation and shifting of major expenses from the current period to the next period.

Therefore, earnings management had always been 
practiced in the way back in accounting preparation. The achievement now is that the introduction of the IFRS and the Sarbanes Oxley Act has made financial statements more value relevance and therefore high quality.

\section{References}

[1] Adaramola Anthony Olugbenga and Oyerinde Adewale Atanda (2014). Value Relevance of Financial Accounting Information of Quoted Companies in Nigeria, Research Journal of Finance and Accounting, vol. 5, No. 8.

[2] Akerlof, G. A. (1970). The market for "Lemons" quality uncertainty and the market mechanism. The quarterly journal of economic $84,488-500$.

[3] Amy Y. Zang (2012). Evidence on the Trade-off between Real Activities Manipulation and Accrual-Based Earnings Management. The Accounting Review. Vol. 87, (2) pp. 675703 .

[4] Badertscher, B. (2011). Overvaluation and the Choice ofAlternative Earnings Management Mechanism. The Accounting Review 86 (September): 149-1518.

[5] Bartov E, Givoly D. and Hayn C. (2002). The Rewards to Meeting or Beating Analysts Forecasts. Journal of Accounting and Economics 33: 173-204.

[6] Bartov, E. Givoly, D. and Hayn C. (2001). The Rewards to Meeting or Beating Earnings Expectations, Working Paper, New York University of California, Irvine and University of California, Los Angeles, May.

[7] Beeker, C. M., Defend, J. Jiambalo and Subramanyam K., (1998). The Effect of Audit Quality on Earnings Management. Contemporary Accounting Research 15 (1): 1-24.

[8] Bhattaeharya, U. Groznik P. and Haslem B. (2002). Is CEO Certification of Earning Numbers Value Relevant? Working Paper Indian University.

[9] Burgstahler, D. C. (1997). Incentives to Manage Earnings to Avoid Earnings Decreases and Losses. Evidence from Quarterly Earnings. Working Paper University of Washington, Seattle, December.

[10] Burgstahler, D. C. and Dichev, D. (1997). Earnings Management to Avoid Earnings Decreases and Losses. Journal of Accounting and Economics 24 (1): 99-126.

[11] Chen, A. Dey, and Lus, (2008). Accrual-Based and Real Earnings Management in the pre and post-Sarbanes-Oxley Period. The Accounting Review 83 (3): 757-787.

[12] Chen, D. Mashruwala, R. and Zach, T. (2010). The use of Advertising Activities to meet Earnings Benchmarks: Evidence Fran Monthly Data. Review of Accounting Studies 15 (4) 808-832.

[13] David Burgstaher, Luzi Hail and Christrian Leuz, (2004). The Importance of Reporting Incentives: Earnings Management in European Private and Public Firms Wharton Financial Institute Centre, Working Paper Series.

[14] Dawn A. Matsumoto (2002). Management Incentives to Avoid Negative Earnings Surprises. The Accounting Review, Vol. 77, (3) pp. 483-514.
[15] Eli Bartov and Daniel A. Cohen (2007). Mechanisms to Meet/Beat Analysts Earnings Expectations in the Pre and Post-Sarbanes-Oxley Era, Law, and Economics Research Paper Series, Working Paper No. 07-18.

[16] Eli Bartov, (1993). The Timing of Asset Sales and Earnings Manipulation. The Accounting Review Vol. 68 (4) pp. 840-855.

[17] Elliott and W. H. Shaw (1988) write-offs as Accounting Procedures to Manage Perceptions. Journal of Accounting Research (Supplement): 91-119.

[18] Elliott, J. A. and Hanna, J. D (1996). Repeated Accounting Write-offs and the Information Content of Earnings. Journal of Accounting-Research 34 (Supplement) 135-155.

[19] Faouzi Mohamed Hamdi, and Mohamed Ali Zarai (2012), Earnings Management to Avoid Earnings Decreases and Losses: Empirical Evidence from Islamic Banking Industry. Research Journal of Finance and Accounting vol. 3, No. 3, 2012.

[20] Field, T., Lyz, T. and Vincent L. (2001) Empirical Research on Accounting Choice. Journal of Accounting and Economics 31 (1-3): 255-308.

[21] Finn Scholer, (2005), Earnings Management to avoid Earning Decreases and Losses. Financial Reporting Research Group, Working Paper R 2005 - 03.

[22] Francois Degeorge, Tayendes Patel and Richard Zckhanser (1999). Earnings Management Incentive to Exceed Threshold, The Journal of Business, vol. 72, No. 1, pp. 1-33.

[23] Gunny, K. A., (2010). The Relation between Earnings Management using Real Activities Manipulation and Future Performance. Evidence from Benchmarks. Contemporary Accounting Research 27 (3): 855-888.

[24] Haifa Chen Qinglana Tang, Y., Hong Jiang, and Zhijun Un, (2010). The Role of International Financial Reporting Standards in Accounting Quality: Evidence from the European Union, Journal of International Financial Management and Accounting 21: 3, 2010.

[25] Healy, P. Wahlen, J. (1999). A Review of the Earnings Management Literature and its Implications of Standard Setting, Accounting Horizons pp. 365-383.

[26] Ivy Xiyina Zhang (2007). Economic Consequences of the Sarbanes-Oxley Act of 2007, Conference Paper in 2005. Journal of Accounting and Economics.

[27] Jennifer Franeis, Ryan Lafond and Per M. Olsson, (2004). Costs of Equity and Earnings Attributes. The Accounting Review, 79, No. 4, pp. 967-1010.

[28] John R, Graham, Campbell R., Harvey and Shiva Rajgopal (2005). The Economic implication of Corporate Financial Reporting. Journal of Accounting and Economics 40, 3-73.

[29] Levitt, A. (1998) The Numbers Game Speech Delivered at NYU Centre for Law and Business, New York September 28.

[30] Mary E. Barth, Wayne R. Landsman, Mark Lang, Christopher William, (2012). Are Based Accounting Amounts Comparable? Journal of Accounting and Economics 54, 68-93.

[31] Mary E. Barth, William H. Beaver, Wayne R. Landsman (2001). The Relevance of Value, Relevance Literature for Financial Accounting Standard Setting: Another View. Journal of Accounting and Economics 31, 77-104. 
[32] Romano, R. (2004). The Sarbanes-Oxley Act and the making of quack Corporate Governance Working Paper, Yale University, NBER and ECGI.

[33] Roychowhury, S. (2006). Earning Management through Real Activities Manipulation. Journal of Accounting and Economics 42 (3): 335-370.
[34] Schipper, R. (1989). Commentary on Earning Management, Accounting Horizon (Dec.) pp. 91-102.

[35] Schuetz, W. (1998). Update of Activities of the SEC Enforcement Division, SEC Financial Reporting Conference, May Pasadena, C. A. (see 6343865982). 